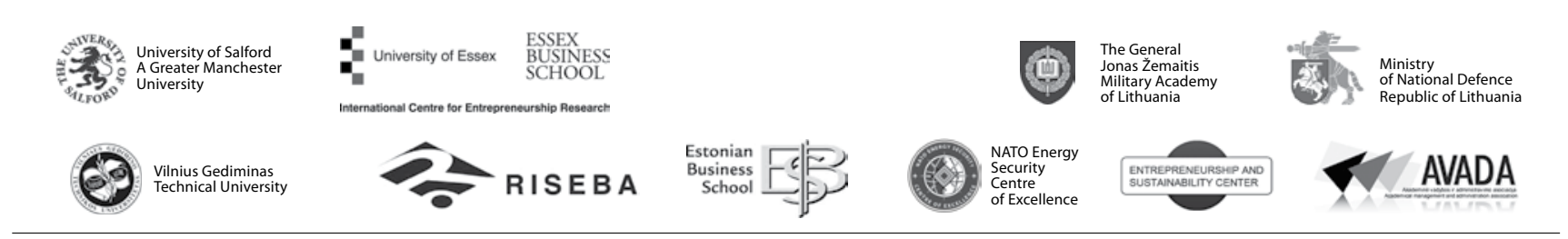

JOURNAL OF SECURITY AND SUSTAINABILITY ISSUES

ISSN 2029-7017 print/ISSN 2029-7025 online

2015 September Volume 5 Number 1

http://dx.doi.org/10.9770/jssi.2015.5.1(1)

\title{
NOT THE INVENTION OF ISIS: TERRORISTS AMONG IMMIGRANTS
}

\author{
Col. Besenyő, János (PhD) \\ Hungarian Defence Forces, Training and Doctrine Center, Doctrinal Analysis and Evaluation Branch, Head of Branch \\ E-mail: besenyo.janos@hm.gov.hu
}

Received 15 June 2015; accepted 30 August 2015

\begin{abstract}
News took wing recently, ISIS is responsible for the migration pressure afflicting the Western World, furthermore ISIS wants to send terrorists among the mass of immigrants into Europe and America, where they - as a "third column" - are going to carry out terrorist attacks, similar to 9/11, at the proper time. This news generated serious debates and emotions in the Western World. Some people say, the threat sould be taken seriously, others claims the ISIS is not able to carry out such well co-ordinated action, and the Western countries has to let in all of the immigrants indiscriminately, apart from the fact, if we are able to integrate them or not.

In my essay I would like to demonstrate, it is problem in the European coutnries and in the United States for a long time, that people with terrorist past mingle in the crowd of immigrants. Later on these people are carrying out terrorist attacks against the countries which generously accommodated them, risking the security of hosting societies, no longer consider these communities as partner but as an enemy needs to be exterminated.
\end{abstract}

Keywords: ISIS, terror, migration, USA, Europe

Reference to this paper should be made as follows: Besenyő, J. 2015. Not the invention of ISIS: Terrorists among immigrants, Journal of Security and Sustainability Issues 5(1): 5-20. DOI: http://dx.doi.org/10.9770/jssi.2015.5.1(1)

JEL Classifications: Z13

\section{Introduction}

The issue of immigrants is deviding the vox populi of the United States, but because of the history of the US, most of the Americans are extraordinarily tolerant and receptive with those people who want to live and doing well in the USA. However, this attitude is changing which is indicative of the statement of congressman Lou Barletta, member of the United States House Committee on Homeland Security, Counterterrorism and Intelligence Subcommittee. In his speach he reminded how dangerous the government's and other organization's plan is, wherein they are preparing to accommodate thousands of Syrian, mainly Muslim refugees (Barletta 2015). Senator Michael McCaul, chairman of the Homeland Security Committee, commited oneself similarly. According to his oppinion, a group of Syrians living in America pose security risk as members of "Jihadist pipeline" (Hohman 2015).

Hard action of the two politician is rather surprising, as both of them are descendants of immigrant families. In contrast with them, some part of the refugees, mainly with Muslim background who is giving the $0.9 \%$ of the 310 Million country, do not want to fit into the American society. (Pew Forum 2012) Though they claim all the benefits, security, principles assured by the country, they are unwilling to accept the traditions, condemning and desiring to exterminate them with - in extreme cases - suicide bombings, or they want to force the majority to recept and admit their own norms (Sharia) (Pew Research Center 2005). 
During a hearing in Senat Michael Steinbach, who is the chief of FBI Counterterrorism Division, made it clear, at present the American security organizations are not able to sieve terrorist hiding among legal or illegal immigrants sent by ISIS (Neumann 2015). ${ }^{1}$ Nicholas Rasmussen, chief of National Counterterrorism Center, had a similar declaration, who reminded the members of the Senate not only to the immigrants, but also to the danger caused by American citizens fiting in Syria and Iraq on the side of different terrorist organizations, then trying to return to the US. The number of these people is around 100 according to the intelligence reports. ( The study of Thomas Hegghammer also affirm the dangerousness of people returning from Syria. In his paper he observed the activity of 945 Muslim immigrants fighting abroad, and found out, that 107 of them (every ninth) carried out terrorist attack after returning home into those Western countries which accommodated them or their families (Hegghammer 2013). Although it seems to be a negligible number, but it is a real threat, so this is the reason why I mention the number of all Muslim citizens fighting in foreign terrorist organizations (in particular ISIS, Al-Nusra) in case of every observed countries (de Roy van Zuijdewijn 2014).

It is a well founded fact and not a fiction, that among immigrants there could be terrorists. Only some of the human rights organizations has another point of view and they also say, Western countries have to accommodate every refugees, no matter where did they come from, what are they purposes and background. In 1960's and '70's many of members of the Muslim Brotherhood with terrorist past were allowed to settle down in the country, later they financed different terrorist attacks from a safe distance through organizations performed social and caritative cover activities. In addition to them many other Iraqi, Afghan and terrorist-suspected people from different countries from the Middle East received asylum then citizenship (Rowman \& Littlefield 2014 in American Foreign Policy Council). Infiltration of terrorist is proved in the study of Janice Kephart written in September 2005. As the member of the group investigated 9/11, she analysed the background of immigrants/ terrorists living in the USA between 1990 and 2004. The article made several interesting ascertainments, from our point of view the most interesting was the fact, that 59 of 94 terrorists took part in different terrorist attacks denied and tried to hide they former activities when they arrived in America, later on they took advantage of the goodwill of authorities and participated in execution of terrorist attacks (Kephart 2005).

We can see similar facts in the case of those 90 thousand people from Iraq who were recognised as refugee and later they received citizenship. Plenty of these people committed murder or other crimes as members of terrorist groups. For example in 2009 two Iraqi, who allegedly persecuted from their homland by radicals, were stroke upon. They settled down in Kentucky and barely impliedly collected datas about military units were being statined in the neighbouring area (Meek, Galli, Ross 2013). One of them was Waad Ramada Alwan, who arrived in the country as an asylum seeker, although he participated in outrages against American soldiers. An FBI investigation led to his unveil when the authorities checked that database wich consist of fingerprints belong to terrorists who committed attacks against American soldiers served in Iraq. According to the report of Gregory Carl (Terrorist Explosive Device Analytical Center - TEDAC) in recent period authrities led investigation in 10-15 similar cases. He also said the problem is not only that more and more people with terrorist background were taken in America, but also at least one hundred Muslim immigrants and young American citizens radicalized by the Muslim immigrants have joined to the armed forces of ISIS, whose returning to America would pose more serious security risk (Neumann 2015; ISIL in Amerika 2015). Most people in Europe only da bit, they presume Americans provoked the hatred of Muslim world with interfering in, so they „deserve" what they receive. Terrorists camouflaged asylum seekers are causing headaches not only to the Americans but to the European countries as well.

As the ISIS is not the first terrorist organization which transported immigrants to European countries, but the GSPC and Ansar al-Islam, which organised the pass into Europe of thousands of immigrants for years. This points to the fact that both of these organizations established a well organised network in Europe as well. ${ }^{2}$ Of course they did not dispread loudly, that they are transporting migrants and terrorists among them - included they own members - into Europe, which activity generates them significant benefit, which were used to finance new terrorist acts (Perry, Negrin 2008). Of course, European countries also made mistake, as with they gracious immigration policy granted refugee status to several terrorist, who first used their new home as a base to commit new terrorist acts, later they considered them as a target (Hegghammer 2013). Although European 
countries tried to neglect the security risks of immigration and its negative effect for years, nowdays more and more people realized the problem and they are concerned about the futer of their closer environment and the continent. In the first place those countries feel threatened, where the refugees firstly arrive in.

\section{Italy}

One of them is Italy, where the immigrants mainly from Syria, Somalia, Eritrea and Northern African countries are arriving in after the Arab Spring. Today from 60 Million people of Italy 3.7\% is Muslim (Pew Forum 2010). Earlier most of the asylum seekers did not want to settle down in Italy, they wanted to go to the Northern countries (France, Switzerland, Austria, Germany, etc.), from where they are deported back, so they stuck in Italy, where they are causing more and more trouble. Terrorists of ISIS appeared among the refugees. Abdelmajid Touilt has just arrested, who took part in organizing terror attack against the Bardo Museum in Tunesia, then he tried to hide among immigrants in Italy (Hohman 2015).

Improbably that he is the only one, according to Libyan sources, people smugglers transporting immigrants to Europe made a deal with Islamic State. According to it, Jihadist controlling some part of the country, allow them to continue people smuggling. In return they have to transfere half of their income to the Islamic State, on the other hand they have to take Islamist fighters with them. It is a huge problem and almost impossible for the European authorities to sieve and detect these terrorists due to the deficient co-operation among European states, which situation could be abused by members of ISIS or other terrorist organizations (Moor 2015). The 2015 report of European border-controll agency, the Frontex also mentions these problems, and indicates, they are not able to filtere neither terrorists hiding among immigrants nor those people who are returning to Western countries from the Syrian-Iraqi operations (Frontex Annual Risk Analysis 2015). Italian authorities are aware of at least five terrorist cells from Balkan Peninsula, who are operating incorporatedly into Albanian, Kosovan, Macedonian and Bosnian communities. They recruited hundreds of volunteers for the ISIS and Al-Nusra and other terrorist groups, whose return carry serious dangers (Neumann 2015; EU Terrorism Situation and Trend Report 2015). It seems terrorist immasked as immigrants arrived in Italy earlier, such as those Afghan and Pakistani men living in Italy, who participated in terrorist activities abroad as members of Al-Qaeda. The group was raided by the police when they started to carry out armed attack planned against the Vatican (Grierson 2015). Several other attempts were foiled committed by Muslim radicals, but the general public did not become aware of them (SIAM 2012). It shows the threat of the country, that in the video recorded the becapitation of 21 Coptic Christian on 15th of February 2015, one of the Islamists pointed to the cost of Italy and said the following: "We will conquer Rome, by the will of Allah" (McDonald-Gibson 2015).

\section{Spain}

Spain, which is also considered as "gate country" is not in light situatin, since $14 \%$ of its 46.5 Million population are immigrants, a significant part of them has Muslim background, their rate in the whole population reaches the 2.1\% (Arango 2013; Pew Forum 2012). Besides the illegal migrants are carrying higher and higher security risk, whose number is permanently groving. While in 2013 the Spanish police captured 7000 immigrants, in 2014 this number was 70\% more, almost 13.000 (Badcock 2015). Of course more people get in and stay illegaly in the country. Most of the Muslim refugees (mainly from Northern Africa and Syria) are arriving in Europe through Ceuta and Melila using fals documents (Corcoran 2015).

Integration of Muslim refugees is not trouble free, in several case they are abusing democratic rules to threat openly the members of inclusive society, and acts committed by them are shocking the common oppinion which makes the hostility to foreigners stronger (Fernandez, Moraga, Ferrer, Saiz 2013). Among refugees there are planty of Moroccans, some of them were sympathizers of Al Qaeda previously, but more and more Moroccans are becoming radical after arriving in Spain, and they are also becoming more and more malevolent with the country which accommodated them (Soeren 2015). Many of the immigrants arrived in Spain used to belong to terrorist organizations and took part in terrorist attacks; after all they reside without problem in the country, where they planned and carried out further terrorist attacks (Bezunartea, López, Tedesco 2009). Most of them 
was 30-40 year old first-generation immigrants, with significant combat experience, mainly from Northern African countries and Syria. They were able to act almost without any kind of control.

According to files of Spanish secret service leaked out by Wikileaks, the number of suspected Islamist terrorist or logistical operatives living in Spain was between 300-1000 in the mid-2000s (Soeren 2010)! Although after bomb outrage in Madrid, immigrants were inspected more carefuly effectively by security and immigration organizations, the terrorists were still able to infiltrate the country. One of them was Abu Musab al-Suri (the Syrian), who was the member of the Syrian Muslim Brotherhood at first, then he escaped from the secret service into Jordan, later on Iraq, where he assist the drilling of Jihadists. Herefrom he fled into France, then he settled down in Spain in 1985, where he acted for 10 years untroubled. He was Spanish citizen he trained terrorists and fought in Afghanistan, and he also promoted the formulation of Al Qaeda. From 1994 to 1997 he worked for the GIA terror organization. Presumably he participated in the French terrorist attacks in 1995, then since 1997 he lived in Afghanistan and took part in organizing terrorist attacks of 9/11. Since 2004 he was on the list of most wanted terrorists in the USA (Kepel 2009).

Such was the Turkish Cengiz Yalcin and his Chechen associates, Eldar Magomedov and Muhamed Ankari Adamov, who wanted to carry out terrorist attacks using remote-controlled airplane in Gibraltar during the London Olimpic Games in 2012. Terrorists who were responsible for outrage in Mumbai, which overtook 166 casualties were members of Lashkar-e-Taiba terror organization. They got trained in Afghanistan and Pakistan before they arrived in India, and they also took part in battle, moreover one of them was a practised bomb maker (Cruickshank 2012). Furthermore those citizens also cause problem for Spain, who are fighting or fought on the side of ISIS on the battlefields of Syria and Iraq, ${ }^{3}$ and some of them has already started to infiltrate back home. Besides of course recruiting of new "volunteers" continues, who are helping not only the ISIS, but they are participating in the actions of other terror organizations. One of them is Benaissa Laghmouchi Baghdadi, who fought in Mali on the side of Islamists, then he avoided prosecution and returned to Spain, where he established the "Sharia4Spain" organization together with his associates, which recruited fighters for ISIS and participated in organizing terrorist actions (Spencer 2014).

\section{Germany}

Germany, which is the main destination of international immigration - wherein Muslims presents a significant number - in Europe, is also endangered (International Migration Report 2013). In these days the second biggest relegious group is the Islam, where 5.8\% of the population (3,8-4,3 Million people) belong, but only 2 Millions of them have German citizenship (Pew Forum 2012; Jessa, Mannewitzi 2014). 70\% of Muslims living in Germany stem from Turkey, they followed by immigrants arrived from Bosnia and Herzegovina, Iran and Morocco (Islam in Germany 2015). It is important to notice, the biggest Afghan and Kurdish community of Europe lives in Germany (Dr. Baser). In summary, most of the immigrants arriving from the third world are Muslim, and their number continues to grow in Germany.

The number of Islamist criminals committing acts of terrorism is also growing - in 2003 67, while in 2009 against 160 suspects were investigated in Germany -, and arrests connected to the Islamist terrorism reached 19 in 2012 (Jessa, Mannewitzi 2014). Beacuse of these in partially, wide social resistance evolved against the Muslim immigrants recently, which best known representative is the Pegida-movement, and more and more ethnic and religious conflict occures (Common Statement on Pegida 2015; Siegel 2015). In 2014 streets of Hamburg became battlefield, after the clash of symphathizers of Islamic State and the Kurds living in the city (Soeren 2014). So the threat caused by ISIS is real, which is confirmed by the datas published by the Federal Office for the Protection of the Constitution (BFV): according to these 680 people from Germany has traveled to the Middle East to fight on the side of terrorist organization (Garmiany 2015). Numbers published by BFV show that the extreme radical Salafist religions became significantly strong in Germany in the last couple of years: in 20113800 Salafists were recorded by the authorities and their number increased to 7300 today (Brandon 2015). In recent years several terrorist attacks were disconcerted by German authorities, which were organized by persons with Muslim background who have been radicalized as German citizens, but there was such failed 
action, which intended to be carried out by Germans (Sauerland Group) who left their former Christian religion and excepted the doctrines of Islam (Cruickshank 2015; Ejkman 2014). The only succesfull Islamist terrorist attack was carried out in 2011 by Arid Uka from Kosovo, who killed two American soldiers at the Franfurt Airport (Jessa, Mannewitzi 2014).

Some of the attackers were members of previous terrorist organizations, they arrived in Germany under cover name, hiding their past, where they started to organize and bring terrorist actions to effect.

One of the most resonanced event was the case of Salim Boukhari, Fouhad Sabour, Lamine Maroni, Aeroubi Beandalis, who tried to blow up the Christmas market of Strasbourg in 2000 (Frankfurt Group, Global Jihad). In another case Youssef Mohamad El Hajdib and Djihad Hamad tried to explode two trains in Cologne, but because of the mistakes made during the preparation of the bombs, the explosive did not come into action. Later it was turned out, Hamad got trained by members of Al Qaeda in a Palestine refugee camp right before he arrived in Germany, so he was sent into Europe as a sleeper agent, ergo he did not became radical in Germany (Rabasa, Benard 2014). Similar person is Abdel-Akher Hammad, who senteced to death in Egypt for terrorist activity, then he fought in Afghanistan, even so in 2000 he was given political asylum in Germany (Moussa 2001).

Besides the above mentioned, Germans have to face those radical Muslims, who were fighting on the side of ISIS and started to leak back in Germany. According to intelligence informations, until now almost 150 terrorists fighting in Syria came back to Germany, who are carrying serious security risk (Weinthal 2014).

\section{Great Brittain}

Great Brittain with its 64 Million inhabitants is also a popular destination for immigrants, which population is in 4,8\% Muslim, mainly from Syria, Eritrea and Pakistan (Hacket 2015; Migration Statistics Quarterly Report 2015). The fact, that some part of immigrants do not want to be integrated in the recipient society is proved by those 104 of 178 arrested Muslim persons who charged by acts of terrorism committed between October 2012 and January 2015, and not to mention the fact that crimes linked to acts of terrorism were mainly committed by Muslims (Shaw 2015; Statistics, Terrorism Arrest).

A dust-raising report which observed migration tendencies pointed out, that many of immigrants got permanent residence permit or citizenship, who committed crimes in their homeland, or even worse, they murdered (Vine 2014). Because the British border authorities do not give due to investigate the background and former activity of asylum seekers, many of such Muslim has traveled in the country, who took part in acts of terrorism earlier (American Foreign Policy Council - The World Almanac of Islamism 2011).

One of them is Adel Abdel Bari, who was sentenced in Egypt for committing different acts of terrorism, dispite he got political asylum in 1993 and until his arrest in 1998 he worked for Al Qaeda (U.S. Attorney's Office 2012). Ibrahim Hussein Idarus also had terrorist background when he arrived in 1996, and after receiving right of asylum, he participated in blowing up two American embassies in Africa (Moussa 2001). British also granted the right of asylum for several Egyptian, who took part in terrorist actions earlier, such as Yasser Tawfiq Ali El-Sirri, Khalid Abdulrahman al-Fawwaz, Abu Hamza al-Masri and Sayed Agami Muhalhal Mu'awwad. Hani al-Sibia, who labeled as "hatredpreacher", is also belongs to them, who got the right of asylum in Great Britain after run away from Egypt, in spite of his tight connections to several terrorist organisation were known, and he referred to the terrorist outrages (subway bombing in 2005) committed against the residents of his hosting country as righteous and justifiable, as well as he inspired Seifeddine Rezgui who smote turists on the beach of Tunisia. Although he did not take part personaly in a single terrorist attack, but he urged others, while he lived as a lord using the social benefits given by the British government. Though in the name of political correctness the government tried to understate the risk of terrorists arriving among immigrants, this attitude has changed already. Recently the British minister of immigration, James Brokenshire pronounced, it has a real risk, that among refugees heading towards the country there are radical Islamists, who can easily abuse the support of large Muslim communities, in particular the Northern Africans, who feel that the British exclude them intentionally (Khosrokhavar). 
For the British, the radicalized Muslims from two and third generations are causing the biggest problem. Such as the terrorists who organized and committed the bombing on 7th of July 2005, or those who prepared outrage against the queen at the and of 2014, but they were not able to implement it, because of the intervene of Sctland Yard (Sawer 2014). It is a more serious risk, if those 700 British citizens who are fighting under the flag of ISIS, would like to return home to Great Britain (BBC News 2015). So the authorities try to bear down those who are recruiting gunmen for ISIS, and they try to keep back Muslims who purpose to go in Syria, and to bring the home-comings to justice, and if it is necessary, in protection of the society, imprison them (Whitehead 2014; Reuters 2015; BBC News 2015).

\section{France}

Immigration in France also hides security riks, and those persons with terrorist past, who mingled in the crowd of refugees, whose sieving out is all the more difficult, because immigrants of Muslim background are giving the 7.5\% of the population (4,7 Million) (Journalist resource 2015; Pew Forumm 2012). ${ }^{4}$

Most of those acts of terrorism which are known in the country are committed by young people from the second and third generation, who radicalized locally, such as Sid Ahmed Ghlam, who murdered a young mother and planned several terrorist attacks against Christian churches, or Yassin Salhi, who shot a selfi and posed on it with the severed head of his own boss, then he uploaded the photo on the internet (Global Jihad 2015; The Guardian 2015). But Chérif Kouachi, Said Kouachi and Amedy Coulibaly are also belong to them, who became widely known apropose of the outrage against Charlie Hebdo (BBC News 2015). Khaled Kelkal is also one of them, who took part in several terrorist attacks i.a. in the outrage which occured on one of the station of RER Railway in 1995. The attack resulted the death of 16 and injury of 300 people (Global Jihad 2009).

In the outrage of Paris two such terrorist assisted - Boualem Bensaid and Smain Ait Ali Belkacem -, who arrived in France from Algeria with terrorist past, but they merged into the mass of immigrants and disappeared from the sight of authorities (Globan Jihad 2009). They were not the first terrorists who arrived as refugee. In 1994 such persons arrived, who personate themselves refugee, however they were trained in Pakistan and Afghanistan and they also took part in battle, then they domiciliated in France (Hussey 2014). Most of the arrivers are members of the Algerian GIA (Groupe Islamique Armé), who are helped out by Algerians or other Northern African immigrants living in France or by Muslims already with French citizenship (Khosrokhavar).

In other cases it has proved, terrorist cloacked to immigrants arrived in France, who committed acts of terrorism or other crimes after years of hiding. In light of this it is understandable, that French authorities take seriously the threat of ISIS leaders in connection with the incorporation of "sleeper agents". However at present those French citizens who infiltrating back from Syria and Iraq, causing bigger headache. Till now they are aware about 1430 persons, who left France to fight on the side of ISIS, 85 of them died in battle. According to the data so far, 11 Jihadists returned from Syria brought to justice, further 152 suspects were commited to prison, and the authorities are expecting more than 200 home-comings (Al Arabiya News 2015). In spite of the alert an "ex-Syrian", Mehdi Nemmouche evaded the atteition of French authorities, but it is also true, he did not do it in France, but in the neighbouring Belgium, where he committed terrorist action on 24th of June 2014, where he killed an employee and three visitors in the Jewish Museum of Brussels during daytime. After a couple of days he captured by the French police, he was equiped with significant number of weapons. Hence French has the doubtful glory, that the first home-comer from Syria who committed terrorist action was their citizen (Dickey 2014).

\section{Belgium}

$10 \%$ of the population of the neighbouring Belgium with 11 Million inhabitants is immigrants, whose significant part is Muslim, their ratio reached 5,9\% of the whole population in 2010, and it is increasing continuously (International Migration Statistics; Pew Forum 2012). According to national security agencies there are at least 20 such cells consisting of Muslim terrorist - around with 120-180 members - are located in Belgium, France, 
the Netherland and Germany, whic are only waiting for to be activated by ISIS. Many of them probably has infiltrated as immigrants into the countries mentioned above (Smith-Spark, Watson, Lister 2015). In case of Belgium it is really easy, since the country is famous about its liberal immigrants policy, it is "opening the gate" almost for everyone (Immigration and Islam in Europe).

Thus the veteran terrorist Abdelkader Hakimi could lived in Belgium, in spite of he was a party in several terrorist actions before he arrived in the country, then he sentenced to 8 years of prisonment, and after his release, he stayed in Belgium. From here he left for Syria, where he is fighting under the flag of ISIS at present (Emmejihad 2014). But he is not the only one. We are aware of several similar person with terrorist past, who lived more in less time undisturbed in the country, such as Ahmed Zaoui, Tarek ben Habib Maaroufi, Abdesattar Dahmane and Baraoui El Ouaer (Coolseat, Struye de Swielande 2007).

In Belgium they are affraid of those 470 radical Belgian citizens fighting in Syria but later they will return, and not without reason (de Bode 2015). As a week after outrage against editorial office of the French Charlie Hebdo, in January 2015 Belgian police raid a three-membered group returned back from Syria only just before the carrying out of a planned terrorist action in Verviers. In heavy firefight two of the terrorist have died, the third was captured. Since then numerous raid carried out in several places of Belgium, among them in the capital, Brussels. People who arrested in Belgium, has already appeared in ISIS's videos availabe online, where they are posing with dead bodies. Terror-alert has raised to level three on a four grade scale (Cruickshank, Almasy, Feyerick 2015).

\section{The Netherlands}

Similar to Belgium the Netherlands is a popular destination of Muslim immigration. In the 17 Million populatio the number of immigrants are around 1965 000, among them there are quite planty of Muslims who gives 6\% of the inhabitants (International Migration Statistics; Pew Forum 2012). Most of them are Moroccans, Turkish, Algerian, Tunisian, Afghan, Iraqi and Somali.

Although in the Netherlands highlited terrorist attack has not committed yet, ${ }^{5}$ the terrorists considered the country as a safe base, a sort of logistics center untill now. Already in the 1980's the Dutch secret service indicated the presence of Muslim radicals which was not significant in that time, but in the 1990's more and more people with terrorist background arrived from Algeria, Bosnia, Chechnya, Egypt and Syria as political refugees, who, although they have rejected the hosting Western society, lived in almost "invisibly". Osama Rushdie Ali Kalifa, one of the leader of Egypt's Islamist Jihad (Al-Jama'a al-Islamia,), also had a terrorist past, who took part in several terrorist outrages along with his connive at crime in his homeland. Terrorist of GIA (Groupe Islamique Armé) carried out several terrorist attacks in France, the Hamas, IBDA-C (İslami Büyükdoğu Akıncılar Cephesi) found safe shelter in Holland, where they organized further terrorist actions, or they produced their material base(Veldhuis, Bakker 2009).

This situation has changed, since the conflicts are becoming stronger between Muslim immigrants and antiimmigrationists (Kern 2013). Nowadays the situation depraved to that point, when Moroccan youngsters are wawing the flag of ISIS, blaring anti-Europe slogans and encouraging to establish a European Islamic State on a demonstration in Hague organised by Muslim immigrants (de Visser 2014). Under the flag of ISIS 200-250 Dutch citizens fight, whose leak back has already started, and who are carrying high security risk (Neumann 2015; National Terrorist Threat Assessment 2015). Of course we can find Dutch not only in ISIS but in Al Nusra Front and other terrorist organizations as well, who are also pose a threat to the safeness of the Netherlands. So the Dutch government aim to neutralize them, for example in 2014 legal procedure has started against a person, who were senteced to three years of prisonment after he returned from Syria, prepared to commit terrorist act and recruited gunmen for ISIS, beside him other perpetrators were also accused of acts of terrorism. ${ }^{6}$

Dutch has learned from their previous mistakes, so their immigrants agencies try to check the early life of Syr- 
ian refugees more effectively, in consequence some of them were expeled, because they provingly committed war crimes in their home countries (Dutchnews 2014).

\section{Sweden}

Sweden is not in an easy situation neither, which has 9,4 Million inhabitants, and a notable number of immigrants (15.1\%) groving permanently due to the welfare achievements (Ramalingam 2012). One third of the immigrants are Muslims, most of them are Iraqi, Iranian, Bosnian, Kurdish and Somali, they give 4.6\% of the population, but this number is increasing continuously (Pew Forum 2012).

Integration of Muslims is not trouble free, sometimes they committed aggressive acts in several cases, which evoked bigger and bigger revulsion and rejection from the recipient society, so the number of clashes between the native Swedish inhabitants and Muslim immigrants is growing (Ramalingam 2012). Today the Swedish government also acknowledges, they are incapable of integrating Muslim immigrants. It is proved by the report published by the Swedish police which presents those residential zones where it is unadvisable to enter not only for the natives but even for the police officers as well (Swedish Police 2004). Many people with terrorist background got political asylum or citizenship, such as Fuad Mohamed Kalaf from Somalia, who recruited warriors and organized terrorist actions, while he was staying in Sweden, then he returned to Somalia in 2004, where he became one of the prominent leaders of Islamic Court of Sharia then the Al Shabab (Ranstorp, Gustafsson, Hyllengren 2015). Mohamed Moumou from Morocco was a similar person who as a member of GICM (Groupe Islamique Combattant Marocain) arrived in the country in the 1980's, later he became citizen in the 1990's. In Sweden he continued to carry out acts of terrorism, and though he took part in the terrorist attack in Casabalnca 2003, he was deported to Sweden by Danish police arrested him at Moroccan government's request. In 2006 he went to Iraq, where he acted as number two leader of Al Qaeda until 5th of October 2008, when he was liquidated by the Americans (Siegel 2008). People with terrorist past arrived among immigrants acted so independently, that the Ansar al Sunnah terrorist organization were able to established a drill camp even in Sweden 2005 (Rogio 2008). In the country many other Iraqi and Chechen refugees were allowed to settle down, who had terrorist background, the they left to Syria to fight. Swedish Security Service mentions in its report from 2010 at least 200 Islamist radicals, 30 of them are extremly dangerous (Säkerhetspolisen 2010).

Swedish authorities are deeply concerned because of those 250-300 Swedish Muslims who have joined to the ISIS terrorist oranization, and althoug the authorities tied to prevent them in returning home, at least 80 are in Sweden again (Ranstorp, Gustafsson, Hyllengren 2015). If ISIS will keep its former promise, Sweden will have to face with serious terrorist actions.

\section{Norway}

Norway has such problems as Sweden have to confrot. From the 5 Millions of inhabitants 805000 are immigrants, they give $15.6 \%$ of the whole population, while Muslims (mainly Pakistani, Iraqi, Iranian, Turkish, Bosnian, Kosovan, Afghan and Somali) give 3.7\% (Statistics Norway 2015; Storhaug 2011; Pew Forum 2012). Since in recent years members of the Muslim community caused several problems, the government has hardened its immigration policy, they try to locate more effectively the immigrants with terrorist past, if they find them, these immigrants will be deported. Many of applications of asylum seekers personated themselves as refugees were refused because they were linked to Al-Nusra, ISIS, Boko Haram or Al-Shabab (Porter 2015; Norway News 2015). Despite many of person with terrorosit background got into the country, where they continued to support terrorist activities.

One of them is Abdukadir Mohamed Abdukadir alias Ikrima, who participated in blowing up American embassy in Kenya 1998, in the outrage in Mombasa 2002 and in other terrorist acts. After all with this kind of past he was allowed to settle down in Norway in 2004, where he lived calmly until 2008, while he contributed to organize other terrorist actions (Neubert, Simmons 2013). The Kurdish Mullah Krekar was not an Islamist when he arrived in 1991, but later he established the Ansar al Islam terrorist organization, which carried out terrorst 
actions in Kurdistan under his leadership, but of course he denyed. In 2006 he was added to the list were the UN enumerated terrorists, in 2007 High Court of Norway declared him as a person who is endangering the security of the state. Although they tried to deport him back to Iraq, they did not succeed due to the long legal struggle. After he mortally threatened the prime minister, he have been sentenced to three years prisonment, later when he was released he appraised the terrorist who attacked Charlie Hebdo, moreover he labeled it as a rightous act, so he was sent back to the prison (Capon 2015). Beside them many other people with terrorist background acted undisturbed in Norway for more or less long term (Vermat 2010).

Although Norwegian authorities are removing more and more illegal immigrants recently, still they are aware of 15000 immigrants who have already been expeled, but they are still in the country carrying security risk (Norway News 2014). Norwegian inhabitants are considering those Norwegians who joined ISIS in Syria and their returning as a risk, so they made such law, which penalize those who are fighting in terrorist organizations and those who are recruiting. According to the newest informations, it concerns at least 60 people (Neumann 2015). As first precedent, two Albanian brothers, Valon Avdyli and Visar Avdyli and a Somalian, Djibril Abdi Bashir were sentenced to years of prisonment for participation in Syrian civil war, and for co-operation with terrorist organization (The Local 2015). Since then another Norwegian citizen, Ishaq Ahmedet was sentenced to for fighting on the side of ISIS in Syria (Norway News 2015). Norwegian citizens have joined not only to ISIS but to the Al Shabab as well, one of them was Hassan Abdi Dhuhulow, who participated in the attack against a mall in Kenya where 67 people died in 2013 (The Independent 2013).

\section{Denmark}

The third northern country which has to face with serious immigration problems is Denmark. The country has 5.5 Million inhabitants, 12.16\% (668 704) of them are immigrants (Statistics Denmark 2015). The ratio of Muslims (Turkish, Bosnian, Iraqi, Palestinian, Pakistani, Iranian, Somali and Afghan) in the whole population is $4.1 \%$ (Pew Forum 2012). The relationship of natives and Muslim immigrants is problematic here too. According to surveys, half of the Danish inhabitants would like if legislators would make more strikt rules concerning the immigration of those who are coming from Muslim countries in order to keep themselves in safe (Lindekilde, Sedgwick 2012). It is understandable in the light of the fact, that many immigrants were allowed to settle in Denmark who have terrorist background, later these people continued their activities (American Foreign Policy Council 2014).

Abdel-Hakem Mohamed Atia Soliman, Mohamed Shaaban Mohamed Hassanein and Mohamed Abdel Halim were members of the Egyptian Al-Gama'a al-Islamiyya terrorist organization when they moved to Denmark, and they had something to do with the attack against the World Trade Center in 1993. Many other members of the Egyptian terrorist organization have settled down in Denmark, who belonged to the network of Omar Abdel Rahman, who planned and organized the attack against World Trade Center. One of the most famous was Abu Talal, who has got refugee status in spite of the opposition of Egypt and the Interpol. Talal was captured by the Croatian police after he tried to co-operate with Bosnians in the Balkan conflict, later he was handed over to the government of USA, who delivered up to Egypt, where he was sentenced to death and executed for acts of terrorism. In Denmark many other members of GIA and different Norther African terrorist organizations found shelter, then they continued to support terrorist acts and guaranteed the ideal, financial and logistical basis (Jensen 2006). One of them was Athmane Mehiri from Algeria, who arrived in Denmark in 1995 as a member of FIS, where he worked for years, then in June 2001 robbed a bank for the Algerian terrorist organization GSPC, but he was captured soon and criminated (Jensen 2006).

The Palestinian Ahmed Abu Laban, die din 2007, also risked the security of Denmark. He was exiled from Egypt and Kuwait as a member of Muslim Brotherhood in 1983. In Denmark He picked up with Abu Talal alQassimy, the leader of Gama'a Islamiya terrorist group. Al-Qassimy fought together with Osama Bin Laden and other leaders of Al Qaeda in Afghanistan, which makes this relationship interesting, then he participated in the terrorist attack of 9/11 (Ammitzbøll, Vidino 2007). Laban acted in Denmark as radical religionist leader, and he also played role in - most of the times - terrorist attacks against Denmark, the newspaper Jylland-Posten 
and its journalist because of the cartoons published in September 2005 (Kepel 2009). He threatened the Denish people, he will "release hell". Although he did not participated phisically in the terrorist acts, but he did not condemned the actions, it seems he even encouraged them (Larsson 2009).

From Denmark 100-150 people have joined terrorist organizations in Syria, despite Denmark gives a second chance to reintegrate for those who come home from Syria (Neumann 2015; Higgins 2014).

\section{Conclusion}

This study was not written make prejudice stronger against Muslim immigrants, actually I acknowledge all the values of Muslim immigrants, which made/make the recipient Western societies rich. Despite we have to see, there are some others, who have terrorist background indeed, who are abusing the quite permissive immigration policy of Western countries, they are arriving in hiding their past, in the Western countries they are carrying out terrorist activities, they are attacking the recipient societies on purpose, questioning their raison d'etre, moreover they are carrying out terrorist attacks against the members of these communities. In my point of view self defence is completely lawful and reasonable against these people. Self defence has to be started with more careful investigation of the background of refugees, and if it is going to turn out any time, that an accomodated refugee is carrying out terrorist activity and endangering the recipient society, there have to be a possibility to send him or her back to that country from where he or she came from.

In the United States the authorities keep count of 2.5 Million Muslim immigrants, and in the European Union 43.5 Million Muslims live who give 5.9\% of the continent's population (Pew Forum 2012). From them the authorities are not able to sieve out every simple terrorist-suspicious person, so we should consider the threat of ISIS, namely they will send terrorist into America or the European countries among immigrants - in the light of cases I have studied -, seriously. Since the leaders of ISIS are not just speeking about the restauration of the caliphate, but they are using every availabe tool - mainly terror - to realize it.

The phenomenon, that hosting societies are becoming more and more irreceptive and intolerant because of the anti-terror measures, helps the terrorist cloacked to immigrants, so the community of the Muslims are going to be more closed together against the recipient societies, and in better case they will look at the more and more brutal terrorist actions as a passive or neutral beholder, or even worse, they will support those actively who take part in the actions. This is the reason why the Western countries have to find a way of co-operation with the Muslim immigrants to make sure, no one will be able to hide behind the mask of immigrants.

\section{Notes}

1. If only Muslims with peaceful intention would arrive into the accomodating countries, this could be also a serious challange, because of the different culture and tradition, and only adapt themselves to the majority without problem. The majority exists as a passive, closed entity inside Western societies, where they take all entitlements (job opportunity, social alimentation), but there is a small part of activity (mostly connected to there life-style) where they take part and join to the recipient societies. Not to mention, there is a small, but significant and dominative, more and more radicalized minority, which specifically hate those countries which gave home them or they parents; they do not want to be an integrated part of society, but they want to force the majority to follow their own religious orders and traditions.

2. According to the Country reports on Terrorism 2014 published by the US Government immigrants are on distinguished place of terrorist's recruitment list, so European counterterror organizations consider as an important part of preventing terrorist attacks to help integration of immigrants, even it is failed sometime.

3. According to competent informations 95 citizens from the country are fighting under the flag of ISIS, which does not seem to be planty in comparison with other European countries, but if we add those circa 1.200 Moroccans who have Spanish residence/work permit, Spain has to face that big danger as the neighbouring French. 
4. According to some forecasts until 2030 France and Belgium will be the two countries in the European Union, where the rate of Muslims will exceed $10 \%$ in the whole population, which is going to expand to 6,86 Million; this fact is caused by the continuous wandering from Islmaic countries, and the higher fertility ratio of Muslim women.

5. The brutal outrage, which is mentioned often and which horrified the liberal Dutch community, committed against Theo Van Gogh was carried out by a second generation Muslim, Mohamed Bouyer, who was born in the Netherlands and he also radicalized there. In this essay I am not surveying this case, neither with those more and more brutal acts, which were committed by second and third generation immigrants. For these the recipient societies are also responsible, while a first generation person with terrorist past requires a different type of approach.

6. It is also crushing, that in 2014 not only in this country, but in Austria, the Czech Republic and in Finland all crimes connected to terrorism were committed by Muslims.

\section{References:}

Ammitzbøll, Pernille, Vidino, Lorenzo 2007: After the Danish Cartoon Controversy, Middle East Quarterly, Winter 2007, pp. 3-11, Available on the Internet: <http://www.meforum.org/1437/after-the-danish-cartoon-controversy >

Arango, Joaqin 2013: Exceptional in Europe? Spain's experience with immigration and integration, Migration Polity Institute, March 2013, Available on the Internet: <http://www.sem-ete.gr/wp-content/uploads/2014/07/TCM-Spaincasestudy.pdf >

Badcock, James 2014: Illegal immigration in Spain up 70 per cent in 2014, The Telegraph, 15 April 2015, Available on the Internet: $<$ http://www.telegraph.co.uk/news/worldnews/europe/spain/11539439/Illegal-immigration-in-Spain-up-70-per-cent-in-2014.html>

Bezunartea, Patricia, López, José Manuel, Tedesco, Laura 2009: Muslims in Spain and Islamic Religious Radicalism, MICROCON Policy Working Paper 8, may 2009, Available on the Internet: <http://www.microconflict.eu/publications/PWP8_PB_JML_LT.pdf $>$

Brandon, James 2015: Germany thwarts terrorist attack, but jihadist treat continues to grow, The Jamestown Foundation, May 15. 2015. Available on the Internet: $<$ http://www.jamestown.org/programs/tm/single/?tx_ttnews\%5Btt_news\%5D=43916\&cHash=45216ddcf494a d3e72b82c71e04b685c\#.VZt7Ck3-19A>

Capon, Felicity 2015: Charlie Hebdo Attacks Made Me 'Happy' Says Notorious Norwegian Cleric, Newsweek, 2/27/15, Available on the Internet: <http://europe.newsweek.com/charlie-hebdo-attacks-made-me-happy-says-notorious-norwegian-cleric-310066>

Coolsaet, Rik, de Swielande, Tanguy Struye 2007: Belgium and counterterrorism policy in the Jihadi era (1986-2007), Egmont Paper 15,2007 , p. 5-8.

Corcoran, Ann 2015: Spain: illegal migrant numbers increase; Syrians lead the pack with phony documents, Refugee Resettlement Watch, April 15, 2015, Available on the Internet: <https://refugeeresettlementwatch.wordpress.com/2015/04/15/spain-illegal-migrant-numbersincrease-syrians-lead-the-pack-with-phony-documents/>

Cruickshank, Paul 2012: Spain 'al Qaeda cell' may have targeted Gibraltar, CNN News, August 6, 2012, Available on the Internet: <http:// edition.cnn.com/2012/08/05/world/europe/spain-terror-arrests/>

Cruickshank, Paul, Almasy, Steve, Feyerick, Deborah 2015: Source: Belgium terror cell has links to ISIS, some members still at large, CNN News, January 17, 2015, Available on the Internet: <http://edition.cnn.com/2015/01/16/world/belgium-anti-terror-operation/>

Cruickshank, Paul 2015: German police thwart Boston-style plot to bomb cycle race, source says, CNN, May 01. 2015. Available on the Internet: < http://edition.cnn.com/2015/04/30/europe/germany-terror-arrests/>

Combelles Siegel, Pascale 2008: Coalition Attack Brings an End to the Career of al-Qaeda in Iraq's Second-in-Command, Publication: Terrorism Monitor Volume: 6 Issue: 21, November 7. 2008, Available on the Internet: <http://www.jamestown.org/programs/tm/ single/?tx_ttnews\%5Btt_news\%5D=34112\&cHash=aecd5d51a9\#.Vagpyk0w-po>

Daly, John. C. K. 2014: Spain Grapples with Growing Islamic State Threat, Terrorism Monitor Volume: 12 Issue: 22, November 2014, Available on the Internet: $<$ http://www.jamestown.org/programs/tm/single/?tx_ttnews\%5Btt_news\%5D=43119\&cHash=6a2a7709eeb8 9e5edfdb1c072967fd73\#.VaA8jk0w-po>

de Visser, Nadette 2014: ISIS's Black Flags Are Flying in Europe, The Daily Beast, 07.28.14. Available on the Internet: $<$ http://www. 
thedailybeast.com/articles/2014/07/27/isis-s-black-flags-are-flying-in-europe.html>

de Bode, Lisa 2015: From Belgium to Syria and back: How an altar boy became an ISIL admirer, Aljazeera Amerika, March 5 2015, Available on the Internet: $<$ http://america.aljazeera.com/articles/2015/3/5/how-one-belgian-went-from-altar-boy-to-isil-fan.html >

de Roy van Zuijdewijn, Jeanine 2014: The Foreign Fighters' Threat: What History Can (not) Tell Us, Perspectives on Terrorism, Vol 8 , No 5 (2014), Available on the Internet: <://www.terrorismanalysts.com/pt/index.php/pot/article/view/378/html>

Dickey, Christopher 2014: French Jihadi Mehdi Nemmouche Is the Shape of Terror to Come, The Daily Beast, 09.09. 2014. Available on the Internet: <http://www.thedailybeast.com/articles/2014/09/09/the-face-of-isis-terror-to-come.html>

Dr. Baser, Bahar: Diaspora politics and Germany's Kurdish question, Available on the Internet: <http://www.kent.ac.uk/politics/carc/ diasporas-and-securitisation/documents/diaspora-politics-and-germanys-kurdish-question.pdf $>$

Eijkman, Quirine 2014: The German Sauerland Cell Reconsidered, Perspectives on Terrorism, 2014, Available on the Internet: < http:/ www.terrorismanalysts.com/pt/index.php/pot/article/view/363/html $>$

Fernandez, Jesus, Moraga, Huertas, Ferrer, Ada, Saiz, Albert: Immigrant Locations and Native Residential Preferences in Spain: New Ghettos? Available on the Internet: <http://www.gatestoneinstitute.org/3780/spain-muslims-kings $>$

Garmiany, Polla 2015: Hundreds of Germans have flocked to ISIS, dozens have died fighting, Rudaw,26.4.2015. Available on the Internet: $<$ http://rudaw.net/english/world/26042015>

Grierson, Jamie: Italy terror cell that plotted to bomb Vatican smashed, prosecutors say, The Guardian, Available on the Internet: $<$ http:// www.theguardian.com/world/2015/apr/24/osama-bin-ladens-purported-former-bodyguards-held-in-italian-terror-raids>

Hacket, Conrad 2015: 5 facts about the Muslim population in Europe, Available on the Internet: <http://www.pewresearch.org/facttank/2015/01/15/5-facts-about-the-muslim-population-in-europe/>

Hegghammer, Thomas 2013: Should I Stay or Should I Go? Explaining Variation in Western Jihadists' Choice between Domestic and Foreign Fighting, American Political Science Review, February 2013, p. 1-15. Available on the Internet: <http://hegghammer.com/_files/ Hegghammer_-_Should_I_stay_or_should_I_go.pdf $>$

Higgins, Andrew 2014: For Jihadists, Denmark Tries Rehabilitation, The New York Times, DEC. 13, 2014, Available on the Internet: $<$ http://www.nytimes.com/2014/12/14/world/for-jihadists-denmark-tries-rehabilitation.html?_r=0>

Hohman, Leo 2015: Congressman slams Obama's Syrian refugee program, WND exclusive, 06.15.2015, Available on the Internet: $<$ http://www.wnd.com/2015/06/congressman-slams-obamas-syrian-refugee-program/>

Hohman, Leo 2015: Terrorist posing as „refugee” nabbed by Coops, Available on the Internet: <http://www.wnd.com/2015/05/terroristposing-as-refugee-nabbed-by-cops/>

Hussey, Andrew 2014: The French Intifada: The Long War Between France and Its Arabs, Macmillan, 2014

Jensen, Michael Taarnby 2006: Jihad in Denmark, an overview and analysis of Jihadi activity in Denmark 1990-2006, DIIS Working Paper no. 2006/35, Available on the Internet: $<$ http://www.cie.ugent.be/documenten/jihad-dk.pdf $>$

Jessa, Eckard, Mannewitzi, Tom 2014: Impact of Counter-Terrorism on Communities: Germany Background Report, Open Society Foundation - Institute for Strategic Studies, 2014, Available on the Internet: <http://www.strategicdialogue.org/Country_Report_ Germany_SF_FINAL.pdf>

Kepel, Gilles 2009: Beyond terror and martyrdom, The future of Middle-East, Harvard University Press, 2009

Kephart, Janice 2005: Immigration and Terrorism, Moving Beyond the 9/11 Staff Report on Terrorist Travel, Available on the Internet: $<$ http://cis.org/articles/2005/kephart.html >

Kern, Soeren 2014: The Islamization of Belgium and the Netherlands in 2013, Gatestone Institute, January 13, 2014, Available on the Internet: $<$ http://www.gatestoneinstitute.org/4129/islamization-belgium-netherlands $>$

Kern, Soeren 2015: Spain: "The Mediterranean Corridor of Jihadism”, Gatestone Institute, Marc 11, 2015. Available on the Internet: $<$ http://www.gatestoneinstitute.org/5368/spain-mediterranean-jihadism>

Kern, Soeren 2014: Germany: Holy War Erupts in Hamburg, Gatestone Institute, october 15. 2014. Available on the Internet: <http:// www.gatestoneinstitute.org/4780/hamburg-holy-war> 
Kern, Soeren 2010: Barcelona: Islamist Stronghold on the Mediterranean, Gatestone Institute, December 16, 2010, Available on the Internet: < http://www.gatestoneinstitute.org/1731/barcelona-islamist-stronghold $>$

Khosrokhavar, Farhad: Terrorism in Europe and the Middle East, Available on the Internet: $<$ http://www.ps.au.dk/fileadmin/site_files/ filer_statskundskab/subsites/cir/pdf-filer/khosrokhavar.pdf>

Larsson, Göran 2009: Islam in the Nordic and Baltic countries, Routledge, 2009

Lindekilde, Lasse, Sedgwick, Mark 2012: Impact of Counter-Terrorism on Communities: Denmark Background Report, Open Society Foundation, 2012, Available on the Internet: $<$ http://www.strategicdialogue.org/Country_report_Denmark_AD_15_Oct_forwebsite.pdf $>$

McDonald-Gibson, Charlotte 2015: How ISIS Threatens Europe, Time, Feb 26, 2015, Available on the Internet: <http://ime.com/3720076/ isis-europe-migrants/>

Meek, James Gordon, Galli, Cindy, Ross, Brian: Exclusive: US May Have Let „Dozens' of Terrorists Into Country As Refugees, abc News, Nov. 20, 2013, QUANTICO, Virginia: Available on the Internet: $<$ http://abcnews.go.com/Blotter/al-qaeda-kentucky-us-dozensterrorists-country-refugees/story?id=20931131>

Moor, Jack 2015: Lack of Co-ordination Leaves EU ,Vulnerable' to Jihadists Posing as Refugees, Newsweek, 1/30/15. Available on the Internet: <http://europe.newsweek.com/lack-coordination-between-eu-members-leaves-bloc-vulnerable-jihadist-303305>

Moussa, Ahmed 2001: Egypt's most wanted, Al-Ahram Weekly Online, 18 - 24 October 2001, Issue No.556 Available on the Internet: $<$ http://weekly.ahram.org.eg/2001/556/11war3.htm>

Neubert, Michele, Simmons, Keir 2013: The terrorist who got away: Why SEAL Team 6 was sent to snatch Ikrima from Somalia, NBC News, Nov 17 2013, Available on the Internet: <http://www.nbcnews.com/news/other/terrorist-who-got-away-why-seal-team-6-wassent-f2D11609353>

Neumann, Peter R. 2015: Foreign fighter total in Syria/Iraq now exceeds 20,000; surpasses Afghanistan conflict in the 1980s, The International Centre for the Study of Radicalisation and Political Violence, 26/01/2015, Available on the Internet: $<\mathrm{http}: / / \mathrm{icsr}$.info/2015/01/ foreign-fighter-total-syriairaq-now-exceeds-20000-surpasses-afghanistan-conflict-1980s/>

Perry, Marvin, Negrin, Howard E. 2008: The Theory and Practice of Islamic Terrorism: An Anthology, Palgrave Macmillan, 2008

Porter, Tom 2015: ISIS and Al-Nusra militants found among UN refugees bound for Norway, International Business Times, June 2, 2015. Available on the Internet: < http://www.ibtimes.co.uk/isis-al-nusra-militants-found-quota-un-refugees-bound-norway-1503983>

Rabasa, Angel, Benard, Cheryl 2014: Eurojihad, Cambridge University Press, 2014

Ramalingam, Vidhya 2012: Impact of Counter-Terrorism on Communities: Sweden Background Report, Open Society Foundation, 2012 , Available on the Internet: <http://www.strategicdialogue.org/Sweden_paper_SF_FINAL.docx.pdf $>$

Ranstorp, Magnus, Gustafsson, Linus, Hyllengren, Peder (2015): From the Welfare State to the Caliphate, How a Swedish suburb became a breeding ground for foreign fighters streaming into Syria and Iraq. Forteign Policy, February 23, 2015. Available on the Internet: $<$ http:// foreignpolicy.com/2015/02/23/from_the_welfare_state_to_the_caliphate_sweden_islamic_state_syria_iraq_foreign_fighters $/>$

Rogio, Bill 2008: Al Qaeda in Iraq's second in command was a Swedish citizen, The Long War Journal, October 16, 2008, Available on the Internet: $<\mathrm{http}: / / \mathrm{www}$. longwarjournal.org/archives/2008/10/al_qaeda_in_iraqs_se.php $>$

Sawer, Patrick 2014: Remembrance Sunday: ring of steel around Queen to foil Cenotaph 'terrorist plot', The Telegraph, 09. Nov 2014, Available on the Internet: <http://www.telegraph.co.uk/news/uknews/terrorism-in-the-uk/11219150/Remembrance-Sunday-ring-ofsteel-around-Queen-to-foil-Cenotaph-terrorist-plot.html $>$

Shaw, Danny 2015: Why the surge in Muslim prisoners? BBC News, 11. March 2015. Available on the Internet: < http://www.bbc.com/ news/uk-31794599>

Siegel, Jacob 2015: In Germany, the Rise of Anti-Islam Terrorism, The Daily Beast, 05.08.15. Available on the Internet: <http://www. thedailybeast.com/articles/2015/05/08/in-germany-the-rise-of-anti-islam-terrorism.html

Smith-Spark, Laura, Watson, Ivan and Lister, Tim 2015: Security boosted as Europe scrambles to handle growing threats, CNN, January 18. 2015. Available on the Internet: <http://edition.cnn.com/2015/01/17/europe/europe-terrorism-threat/>

Spencer, Robert 2014: Islamic State: "We Will Take Spain Back" JihadWatch, August 17, 2014, Available on the Internet: <http://www. jihadwatch.org/2014/08/islamic-state-we-will-take-spain-back> 
Veldhuis, Tinka and Bakker, Edwin 2009: Muslims in the Netherlands: Tensions and Violent Conflict. MICROCON Policy Working Paper 6, Brighton: MICROCON. 2009. Available on the Internet: http://www.microconflict.eu/publications/PWP6_TV_EB.pdf>

Vermat, Emerson 2010: Norway and Sweden: A Safe Haven for Dangerous Islamist Terrorists, PipeLineNews.org, August 16, 2010, Available on the Internet: $<$ http://www.pipelinenews.org/2010/aug/19/norway-sweden-a-safe-haven-for-dangerous-islamist.html $>$

Vine, John: An Inspection of Nationality Casework, John Vine CBE QPM, Independent Chief Inspector of Borders and ImmigrationAprilMay 2014, Available on the Internet: <http://icinspector.independent.gov.uk/wp-content/uploads/2014/12/Nationality-Report-web.pdf $>$

Weinthal, Benjamin 2014: US intelligence: Islamic State fighters pose as Syrian refugees to enter Europe, The Jerusalempost, 10.05. 2014. Available on the Internet: <http://www.jpost.com/International/US-intelligence-Islamic-State-fighters-pose-as-Syrian-refugees-toenter-Europe-378084>

Whitehead, Tom 2014: Suspected Anjem Choudary associate allegedly tries to head for Syria posing as illegal immigrant, The Telegraph, 01. Dec 2014, Available on the Internet: <http://www.telegraph.co.uk/news/worldnews/middleeast/syria/11266542/Suspected-AnjemChoudary-associate-allegedly-tries-to-head-for-Syria-posing-as-illegal-immigrant.html>

15,000 Illegal Immigrants Refusing to leave Norway, Norway News, 04.09.2014. Available on the Internet: <http://www.norwaynews. com/en/ view.php?73aElA58d4ohc672R6Z353Cw4984azS94544Ncv084cQJT88eWPc38>

A Common Statement on the Evolution of the PEGIDA Movement throughout Europe, Monday, 30th March 2015, Available on the Internet: $<$ http://www.jef.de/fileadmin/files_jef-d/dokumente/Common_Statement_on_PEGIDA_final_new.pdf $>$

American Foreign Policy Council: The World Almanac of Islamism: 2014, Rowman \& Littlefield, 2014

American Foreign Policy Council: The World Almanac of Islamism: 2011, Rowman \& Littlefield, 2011

Barletta: U.S. Lacks Intel to Admit Syrian Refugees, Available on the Internet: <http://barletta.house.gov/media-center/press-releases/ barletta-us-lacks-intel-to-admit-syrian-refugees>

British jihadist Imran Khawaja jailed for 12 years, BBC News, 6 February 2015, Available on the Internet: http://www.bbc.com/news/ uk-31166062

Boualem Bensaid \& Smaim Belkacem 2009, Global Jihad, August 31, 2009, Available on the Internet: http://www.globaljihad.net/?p=4091

Charlie Hebdo attack: Three days of terror, BBC News, 14 January 2015. Available on the Internet: http://www.bbc.com/news/worldeurope-30708237

Convicted European top terrorist Abdelkader Hakimi has traveled to Syria, emmejihad, Available on the Internet: Available on the Internet: https://emmejihad.wordpress.com/2014/06/07/convicted-european-top-terrorist-abdelkader-hakimi-has-traveled-to-syria/

Country reports on Terrorism 2014, Available on the Internet: Available on the Internet: http://www.state.gov/documents/ organization/239631.pdf

European Union Terrorism Situation and Trend Report 2015, EUROPOL, Available on the Internet: https://www.europol.europa.eu/ content/european-union-terrorism-situation-and-trend-report-2015

First three jailed under Norway's new Isis law, The Local, 08 May 2015, Available on the Internet: http://www.thelocal.no/20150508/ first-convictions-under-norways-new-isis-law

France, Islam, terrorism and the challenges of integration: Research roundup, Journalistresource 2015. Available on the Internet: http:// journalistsresource.org/studies/international/conflicts/france-muslims-terrorism-and-challenges-of-integration-research-roundup

Frankfurt Group, Global Jihad, Available on the Internet: http://www.globaljihad.net/?p=2691

French terror suspect sent macabre selfie to contact in Syria, TheGuardian, 29. June 2015. Available on the Internet: http://www. theguardian.com/world/2015/jun/29/french-terror-suspect-sent-macabre-selfie-to-contact-in-syria

Frontex - Annual Risk Analysis 2015, Available on the Internet:http://frontex.europa.eu/assets/Publications/Risk_Analysis/Annual_ Risk_Analysis_2015.pdf

Immigrants and Norwegian-born to immigrant parents, 1 January 2015, Statistics Norway, 4 March 2015, Available on the Internet: http:// www.ssb.no/en/innvbef

Immigrants and their descendants, Statistics Denmark, 2015. Available on the Internet: http://www.dst.dk/en/Statistik/emner/indvandrere- 
og-efterkommere

Immigration and Islam in Europe, euro-islam.info, Available on the Internet: http://www.euro-islam.info/key-issues/immigration/

International Migration Report 2013, United Nations, Available on the Internet: http://esa.un.org/unmigration/documents/ worldmigration/2013/Full_Document_final.pdf

International Migration Statistics, Migration Policy Institute, Available on the Internet: http://www.migrationpolicy.org/programs/datahub/international-migration-statistics

ISIL in Amerika: Domestic terror and radicalization, Thursday, February 26, 2015 - House of Representatives, Subcommitte on crime, terrorism, homeland security, and investigation committe ont he judiciary, Washington, DC. Available on the Internet: http://judiciary. house.gov/_cache/files/121d6120-6f86-4b4e-a39b-7076fa8c7825/114-6-93527.pdf

ISIL, al-Shabaab and Boko Haram had all tried to claim asylum in Norway, Norway News, 24.03.2015. Available on the Internet: http:// www.norwaynews.com/en/ view.php?738DlB58dgljc672X36253Hsba84bTQ34544Ocs084kVQD88ePJb28

Islam in Germany, Euro-Islam.Info, http://www.euro-islam.info/country-profiles/germany/

Islamic Extremism: Common Concern for Muslim and Western Publics, Support for Terror Wanes Among Muslim Publics - PewResearch Center, July 14. 2005. Available on the Internet: http://www.pewglobal.org/2005/07/14/islamic-extremism-common-concern-for-muslimand-western-publics/

Khaled Kelkal, 2009: Global Jihad, August 31, 2009, Available on the Internet: http://www.globaljihad.net/?p=4090

Kenyan mall attack: Norweigan suspected of being attacker named as Hassan Abdi Dhuhulow, as chilling new video is released, The Independent, Friday 18 October 2013, Available on the Internet: http://www.independent.co.uk/news/world/africa/kenyan-mall-attacknorweigan-suspected-of-being-attacker-named-as-hassan-abdi-dhuhulow-as-chilling-new-video-is-released-8886653.html

Less than 100 British jihadists prosecuted for Syria terrorism, RT UK, January 23, 2015, Available on the Internet: http://rt.com/ uk/225615-uk-jihadi-prosecution-rates/

Migration Statistics Quarterly Report, May 2015, Available on the Internet: http://www.ons.gov.uk/ons/rel/migration1/migrationstatistics-quarterly-report/may-2015/stb-msqr-may-2015.html

Nearly half of European militants in Syria, Iraq are French: report, Al Arabiya News, 08.04.2015. Available on the Internet:http://english. alarabiya.net/en/News/middle-east/2015/04/08/

Norwegian court convicts man of fighting for militants in Syria, Norway News, 14.07.2015, Available on the Internet:http://www. norwaynews.com/en/ view.php?73X3854XPb4822v285kif844SO288bT476BA1353J5I8

SIAM Security Impact Assessment Measures, Past Events \& Threat Scenarios, Interdisciplinary Center for Technology Analysis \& Forecasting At Tel Aviv University, 2012, Available on the Internet: https://www.tu-berlin.de/fileadmin/f27/PDFs/Forschung/SIAM/6.1_ Discourse_Analysis_Results.pdf

Sid Ahmed Ghlam planned attacks on churches in Paris, Global Jihad, April 22, 2015, Available on the Internet: http://www.globaljihad. net $/ \mathrm{p}=13126$

Statistics, Terrorism arrests - analysis of charging and sentencing outcomes by religion, Gov.Uk. 2013.

Summary of the 39th edition of the National Terrorist Threat Assessment for the Netherlands (DTN39), June 2015, Available on the Internet:https:/english.nctv.nl/publications-products/Terrorist-Threat-Assessment-Netherlands/index.aspx

Swedish police: 55 official no-go zones, The Sweden report, October 29, 2004, Available on the Internet: http://swedenreport. org/2014/10/29/swedish-police-55-official-no-go-zones/

Terrorism arrests - analysis of charging and sentencing outcomes by religion, GOV.UK. 12 September, 2013, Available on the Internet: https://www.gov.uk/government/publications/terrorism-arrests-analysis-of-charging-and-sentencing-outcomes-by-religion/terrorismarrests-analysis-of-charging-and-sentencing-outcomes-by-religion

The Global Religious Landscape A Report on the Size and Distribution of the World's Major Religious Groups as of 2010, Pew Forum, 2012. Available on the Internet: http://www.bc.edu/content/dam/files/centers/jesinst/pdf/Grim-globalReligion-full.pdf

The Netherlands wrestles with Syrian 'war criminal' refugees, October 29, 2014, Available on the Internet:http://www.dutchnews.nl/ news/archives/2014/10/the-netherlands-wrestles-with-syrian-war-criminal-refugees/ 
JOURNAL OF SECURITY AND SUSTAINABILITY ISSUES

ISSN 2029-7017 print/ISSN 2029-7025 online

Three Alleged International Terrorists Extradited from Great Britain, U.S. Attorney's Office October 06, 2012, https://www.fbi.gov/ newyork/press-releases/2012/three-alleged-international-terrorists-extradited-from-great-britain

Violence promoting Islamist extremism in Sweden, Säkerhetspolisen, 2010, Available on the Internet: http://www.sakerhetspolisen.se/do wnload/18.4f0385ee143058a61a89f3/1392294843261/Reportonviolence-promotingIslamistextremisminSweden.pdf

Who are Britain's jihadists? BBC News, 25 June 2015, Available on the Internet: http://www.bbc.com/news/uk-32026985 